University of Texas Rio Grande Valley

ScholarWorks @ UTRGV

$3-2014$

\title{
Environmental correlates of assemblages of fishes in the Tilostoc River of central Mexico
}

Juan Manuel Rivas-González

Felipe de Jesús Rodríguez-Romero

María de Lourdes Ruiz-Gómez

Diego Alfonso Viveros-Guardado

Christopher M. Taylor

The University of Texas Rio Grande Valley

Follow this and additional works at: https://scholarworks.utrgv.edu/bio_fac

Part of the Biology Commons

\section{Recommended Citation}

Juan Manuel Rivas-González, Felipe de Jesús Rodríguez-Romero, María de Lourdes Ruiz-Gómez, Diego Alfonso Viveros-Guardado, and Christopher M. Taylor "Environmental correlates of assemblages of fishes in the Tilostoc River of central Mexico," The Southwestern Naturalist 59(1), 15-21, (1 March 2014). https://doi.org/10.1894/F03-RJE-31.1

This Article is brought to you for free and open access by the College of Sciences at ScholarWorks @ UTRGV. It has been accepted for inclusion in Biology Faculty Publications and Presentations by an authorized administrator of ScholarWorks@ UTRGV. For more information, please contact justin.white@utrgv.edu, william.flores01@utrgv.edu. 


\title{
ENVIRONMENTAL CORRELATES OF ASSEMBLAGES OF FISHES IN THE TILOSTOC RIVER OF CENTRAL MEXICO
}

\author{
Juan Manuel Rivas-González,* Felipe de Jesús Rodríguez-Romero, María de Lourdes Ruiz-Gómez, \\ Diego Alfonso Viveros-Guardado, and Christopher M. Taylor
}

\author{
Facultad de Ciencias, Universidad Autónoma del Estado de México, Instituto Literario Numero 100 Centro, Toluca, \\ Estado de México, C.P. 50000 (JMRG, FJRR, MLRG) \\ Universidad Autónoma del Estado de Morelos, Avenida Universidad 1001, Colonia Chamilpa, Cuernavaca, Morelos, México, \\ C.P. 62209 (DAVG) \\ Department of Biology University of Texas-Pan American, Edinburg, TX 78539 (CMT) \\ *Correspondent: manuel.rivas@uaem.mx
}

\begin{abstract}
Ordination, correlation, and regression analyses were used to identify trophic and taxonomic distributional patterns of fishes in the Tilostoc River (located west of Valle de Bravo Lake in the Middle Balsas Basin, central Mexico) and associations of these patterns with environmental variables. Nonmetric multidimensional scaling analysis indicated that trophic and taxonomic assemblages corresponded similarly to measured environmental gradients, especially elevation and velocity of currents. We also compared the trophic structure of assemblages of fishes of the Tilostoc River to that of Terreros Creek, a temperate system of similar size and species richness but with a taxonomically different group of species. The two basins were significantly different, indicating strong historical constraint on trophic structure. Our trophic matrix for Tilostoc River was strongly correlated with the taxonomic matrix.

RESUMEN-Se utilizaron análisis de ordenación, de correlación y de regresión para identificar los patrones de distribución tróficos y taxonómicos de peces en el río Tilostoc (situado al oeste del lago Valle de Bravo en la cuenca media del Balsas, en el centro de México) y las asociaciones de estos patrones con variables ambientales. El análisis de escalamiento multidimensional no métrico indicó que los conjuntos tróficos y taxonómicos correspondían de manera similar a los gradientes ambientales medidos, especialmente la elevación y la velocidad de las corrientes. También comparamos la estructura trófica de los ensambles de peces del río Tilostoc con la del arroyo Los Terreros, un sistema templado de similar tamaño y riqueza de especies, pero con un grupo taxonómicamente diferente de especies. Las dos cuencas fueron significativamente diferentes, lo que indica una fuerte restricción histórica sobre la estructura trófica. Nuestra matriz trófica del río Tilostoc estuvo fuertemente correlacionada con la matriz taxonómica.
\end{abstract}

Mexico is considered a megadiverse country regarding its biological resources and biodiversity hotspots (Mittermeier and Mittermeier, 1997). Its aquatic ecosystems are highly diverse and varied, containing ca. 2,212 species of fishes (Comisión Nacional para el Conocimiento y Uso de la Biodiversidad, 1998). Freshwater ecosystems in Mexico alone harbor ca. 560 species. Historical differences among river basins contribute to high levels of endemnicity; for example, the Lerma-Chapala-Santiago system contains 57 extant species, 33 of which are endemic to the basin (Miller, 2005).

Mexico suffers from many of the environmental issues and problems that are common around the world, including overexploitation of natural resources, pollution, and the concomitant loss of biodiversity (Organización para la Cooperación y el Desarrollo Económico, 1998; Instituto Nacional de Estadística Geografía e Informática, 2000). Freshwater ecosystems are among the most impacted because they receive pollutants from domestic, industrial, and agricultural activities. Rivers and streams also have undergone considerable dewatering for municipal and agricultural use and are struggling with the impacts of exotic species (Contreras-Balderas et al., 2008). These changes have amounted to devastating losses of biodiversity (Matthews, 1998; Wooton, 1990), and rates of extinction in Mexico are among the highest in the world (Harrison and Stiassny, 1999). ContrerasMacBeath (2005) reported that 20 species of freshwater fishes in Mexico are already extinct $(4 \%)$ and $>36 \%$ are seriously threatened with extinction.

Within the context of this loss in freshwater biodiversity, it is imperative that we continue to identify important environmental factors (including stressors) that contribute to the patterns of distribution and abundance of freshwater fishes. In the tropics and subtropics of Mexico, natural variation in precipitation leads to fairly predict- 
a

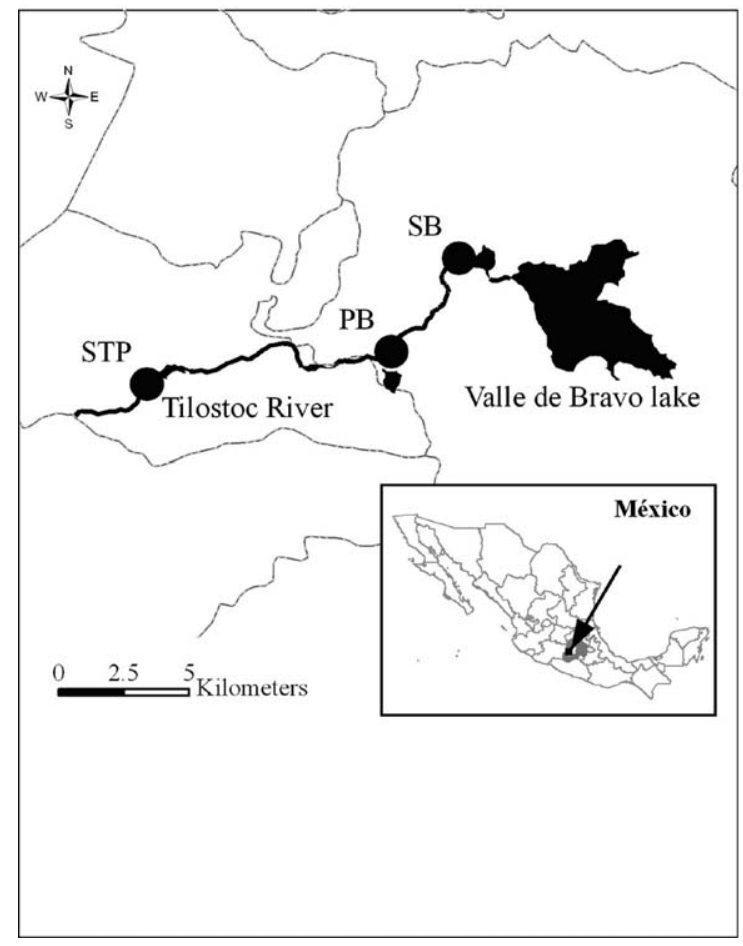

b

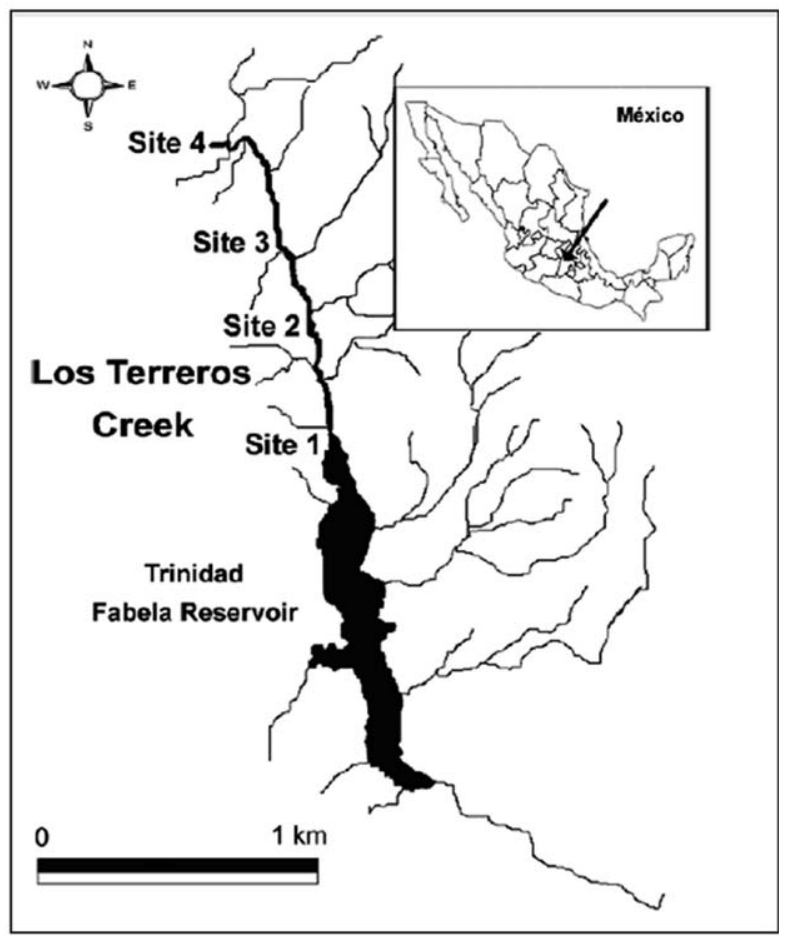

FIG. 1-a) Map of Tilostoc River showing the location of sampled sites in central Mexico. Sites include Santa Barbara (SB), Planta de Bombeo (PB), and Santo Tomas de los Platanos (STP). b) Map of Los Terreros Creek in central Mexico showing the location of sampled sites, modified from Ruiz-Gomez et al. (2008).

able changes in discharge and availability of habitat, which impact communities of fishes in streams. In the dry season, rivers are reduced to small, often isolated pools that limit dispersal opportunity; whereas, in the rainy season, the volume of water increases, forming a continuum that facilitates dispersal (Wootton, 1992; Matthews, 1998; Moyle and Cech, 2000). Other factors influencing distribution and abundance of fishes include anthropogenic impacts to connectivity of streams (such as dams and dewatering), which disrupt the natural flow and alter the dynamics of local immigration and extinction (Taylor et al., 2005). Unfortunately, there is a lack of information on diversity and distributions of fishes in much of Mexico, and losses in biodiversity are accumulating faster than documentation in surveys and inventories (Contreras-MacBeath, 2005); as a consequence, the direct effects of environmental and anthropogenic disturbances in structuring assemblages of Mexican fishes are poorly understood.

The objectives of our study were to examine the role of local environmental factors in structuring assemblages of fishes in the Tilostoc River, as defined taxonomically and based on trophic groupings. We also compared the trophic structure of assemblages of fishes in the Tilostoc River to those in Terreros Creek, a temperate system in the Lerma River basin similar in size to the Tilostoc River, ca. $86 \mathrm{~km}$ north of our study sites. These two systems have historically distinct fishes with only one shared species.
However, because composition of species is potentially related to environmental factors, such as climate, type of habitat, etc., we predicted that the trophic structures would not be historically constrained and would show considerable similarity, as species may consume similar types of prey and have similar dynamics in populations.

Materials and Methods-The Tilostoc River is located in the state of Mexico, west of Valle de Bravo Lake in the middle Balsas Basin (Fig. 1a). The river drains $32 \mathrm{~km}^{2}$ and has a length of ca. $20 \mathrm{~km}$, until confluencing with the Tuzantla River. The region has an average annual rainfall of $33 \mathrm{~cm}$, an average temperature of $22^{\circ} \mathrm{C}, 1.646 \mathrm{~mm}$ of annual evaporation, and a humid, semihot climate.

We sampled three sites along the Tilostoc River: 1) Santa Barbara $\left(19^{\circ} 12^{\prime} 50.4^{\prime \prime} \mathrm{N}, 100^{\circ} 11^{\prime} 52.5^{\prime \prime} \mathrm{W}\right)$; 2) Planta de Bombeo $\left(19^{\circ} 10^{\prime} 28.5^{\prime \prime} \mathrm{N}, 100^{\circ} 17^{\prime} 21.3^{\prime \prime} \mathrm{W}\right)$; 3) Santo Tomas de los Platanos $\left(19^{\circ} 10^{\prime} 2.60^{\prime \prime} \mathrm{N}, 100^{\circ} 18^{\prime} 33.0^{\prime \prime} \mathrm{W}\right)$. Each site was separated by at least $10 \mathrm{~km}$. Santa Barbara, the higher locality $(1,726 \mathrm{~m}$ in elevation), was characterized by a homogeneous channel with constant current velocity and dominated by sand-rock substratum. The riparian vegetation consisted mainly of grass, Eucalyptus, and thorny shrubs. However, Planta de Bombeo $(1,048 \mathrm{~m})$, in the middle of the altitudinal range, was highly impacted by human activities, including heavily disturbed riparian vegetation. The construction of a dam modified the channel and flow of water, which became slower. The dominant substratum in this site was sand-rock. Santo Tomas de los Platanos, the lowest site $(1,010 \mathrm{~m})$, was the least disturbed locality surrounded by well-preserved riparian vegetation. The 
TABLE 1-Total counts and relative and total abundance of each species collected during three seasons in three localities of the Tilostoc River, State of Mexico.

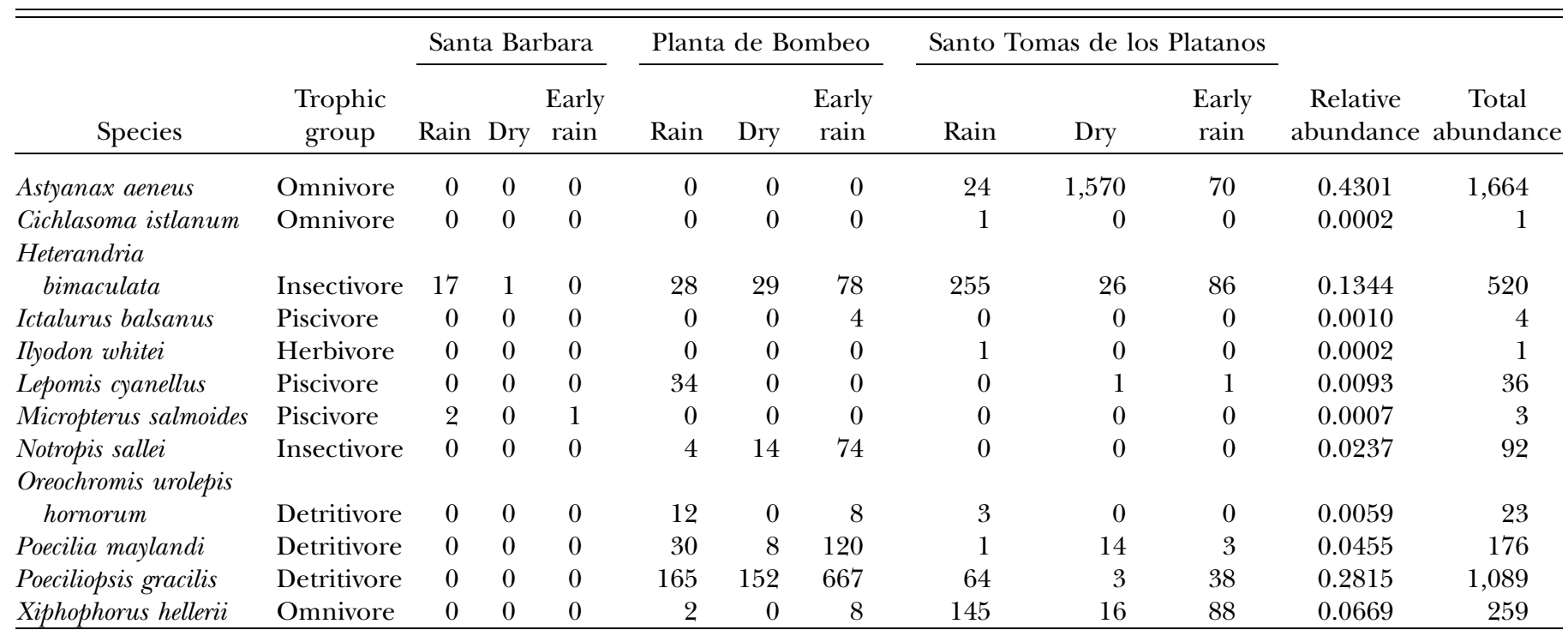

habitat was diverse, mainly dominated by several sequences of riffle-pools, which allowed the establishment of different microhabitats.

The area presents two marked seasons during the year, depending on the amount of precipitation in a given month. This is important to understand the dynamics of habitat on the river, as they can change dramatically depending on the season. During the dry season, the flow is interrupted and several isolated pools appear, whereas, during the rainy season, the river is characterized by continuous flow. The rainy season occurs from June-September, whereas the dry season occurs from October-April. To determine whether the two seasons had an impact on the structure of assemblages, we surveyed the localities on three occasions: at the start of the rainy season (July); during the rainy season (September); at the end of the dry season (May).

We sampled fishes with a seine of 3.0-m (length) by $1.5-\mathrm{m}$ (depth) by 5.0-mm (size of mesh) in size. At each site, we made ca. 12 hauls with the seine depending on site and season, and we covered all types of habitat that occurred. The number of hauls varied depending on sites, season, and availability of habitat. Because the sampling sites were physically quite similar across localities, we are confident that seining effort and data on abundance provide a good representation of the structure of assemblages of fishes at sampled localities. All fishes collected were fixed in 10\%-formalin solution in the field and transported to the laboratory for enumeration and identification. The specimens were deposited in the Ichthyological Collection of the Center for Biological Resources Research, Autonomous University of the State of Mexico, Toluca, Mexico.

Trophic characterization for each species from both systems was determined for adult stages, based on published data for the surrounding area (Zarat and Rand, 1971; Trewavas, 1983; Mills and Vevers, 1989; Contreras-MacBeath and Soto, 1991; Trujillo and Diaz-Pardo 1996; Billard, 1997; Bussing 1998; Trujillo, 1998a, 1998b; Trujillo and Toledo, 2007; R. Froese and D. Pauly, www.fishbase.org). We classified these species into five trophic guilds (Table 1): detritivores; omnivores; insectivores; herbi- vores; piscivores. At each site, we measured several environmental variables including temperature (degrees Celsius), dissolved oxygen (milligrams per liter), $\mathrm{pH}$, conductivity (milliSiemens per centimeter), and total dissolved solids (milligrams per liter). We characterized the types of habitat (riffle, pool, backwater, and channel) in each site according to Hawkins et al. (1993) and recorded altitude, maximum flow velocity (meters per second), maximum depth (meters) and substrate (sand, sand-rock, siltrock, silt-sand, and silt-sand-rock).

For our comparative analysis of trophic structure, we used data from Los Terreros Creek, a third-order and fourth-order stream (Fig. 1b) located ca. $80 \mathrm{~km}$ from the Tilostoc River in the Lerma Basin. Like the Tilostoc River, Los Terreros Creek has been impacted by human activities such as grazing, introduction of exotic species (Chirostoma carpio and C. humboldtianum), and the construction of a dam that has interrupted the natural water course (Ruiz-Gomez et al., 2008). In this system, sampling was conducted by seine during the dry and rainy seasons. Sampling techniques and details are described in Ruiz-Gomez et al. (2008).

The count data for abundance of site-specific species and trophic groups (only for adult stages) were square-root transformed to reduce the effects of highly abundant species on the analyses. We used nonmetric multidimensional scaling to assess temporal variation in assemblages at each site and to examine among-site differences in overall structure of assemblages and to compare the trophic structure of assemblages of fishes in the Tilostoc River to that of Los Terreros Creek, a temperate stream of similar size and species richness but with a taxonomically different group of species. Nonmetric multidimensional scaling is an indirect ordination technique designed to summarize complex data on community (Gauch, 1982). Because it is not based on any distributional assumptions (McCune and Grace, 2002), nonmetric multidimensional scaling is well suited for use with ecological data and is not plagued with problems of other ordination methods such as correspondence analysis and detrended correspondence analysis (Wartenberg et al., 1987; Jackson and Somers, 1991; 
TABLE 2- Values of Pearson's correlations (from nonmetric multidimensional scaling analyses, NMS) of selected environmental variables for taxonomic and trophic groups of fishes in the Tilostoc River, State of Mexico.

\begin{tabular}{|c|c|c|c|c|}
\hline \multirow[b]{2}{*}{ Variables } & \multicolumn{2}{|c|}{ Taxonomic groups } & \multicolumn{2}{|c|}{ Trophic groups } \\
\hline & NMS 1 & NMS 2 & NMS 1 & NMS 2 \\
\hline Width (m) & 0.391 & -0.386 & 0.307 & -0.210 \\
\hline Temperature $\left({ }^{\circ} \mathrm{C}\right)$ & -0.401 & -0.174 & -0.244 & -0.257 \\
\hline Current velocity $(\mathrm{m} / \mathrm{s})$ & 0.420 & -0.461 & 0.523 & 0.518 \\
\hline Water temperature $\left({ }^{\circ} \mathrm{C}\right)$ & -0.645 & 0.507 & -0.679 & -0.664 \\
\hline Total dissolved solids $(\mathrm{mg} / \mathrm{L})$ & -0.395 & -0.327 & -0.253 & -0.029 \\
\hline Conductivity $(\mathrm{mS} / \mathrm{cm})$ & -0.455 & -0.083 & -0.330 & -0.257 \\
\hline
\end{tabular}

Legendre and Legendre, 1998). The technique is based on an iterative search algorithm that minimizes departure from monotonicity in the relationship between dissimilarity in the original data matrix and distances in the reduced ordination space (McCune and Grace, 2002). This provided a convenient and interpretable picture of change in assemblages of fishes across spatial and temporal gradients. Before using nonmetric multidimensional scaling, we computed Bray-Curtis distances among all sample units and followed the general procedure outlined by McCune and Grace (2002). The analyses were conducted with PC-ORD software (McCune and Mefford, 2006).

We performed multiresponse permutation procedures to examine the importance of sites (spatial), seasons (temporal), and type of habitat in separating assemblages of fishes. Multiresponse premutation is a nonparametric procedure for testing differences between two or more groups; the advantage of this method is that it does not involve assumptions (such as multivariate normality and homogeneity of variances) that are seldom met with ecological data on community (McCune and Grace, 2002). Because the trophic matrix was built from the taxonomic matrix, we anticipated some degree of redundancy in the two matrices; we used the Mantel test with a permutation procedure to evaluate the independence of taxonomic and trophic matrices. We compared our trophic groups from the Tilostoc River basin to those from Los Tererros Creek in the Lerma River basin, which has a different biogeographic history and only shares one species with the Tilostoc River.

RESUlts-We collected 3,868 fishes representing five orders (Cypriniformes, Cyprinodontiformes, Characiformes, Perciformes, and Siluriformes), seven families (Cyprinidae, Goodeidae, Poeciliidae, Characidae, Centrarchidae, Cichlid, and Ictaluridae), and 12 species (Table 1). Nonmetric multidimensional scaling and correlation analyses indicated that trophic and taxonomic assemblages varied in similar ways. This was not surprising, because taxonomic and trophic matrices were strongly correlated (Mantel matrix correlation) with each other $(r=0.88 ; P<0.0001$, based on 10,000 permutations).

Taxonomic and trophic analyses suggested that structure of the local assemblage was influenced predominantly by site-specific differences (spatial effects; $\mathrm{A}=$
$0.211, P=0.001$ and $\mathrm{A}=0.303, P=0.001$; respectively). There was no significant influence of season $(\mathrm{A}=0.009, P$ $=0.595$ and $\mathrm{A}=-0.025, P=0.685)$ or type of habitat (A $=0.021, P=0.250$ and $\mathrm{A}=-0.023, P=0.062)$. Nonmetric multidimensional scaling performed on the taxonomic matrix produced two axes representing gradients in structure of assemblages of fishes. Environmental correlations with these axes are shown in Table 2. Both axes cumulatively accounted for $81.5 \%$ of the variation in the original taxonomic matrix. The second axis accounted for most of the variation $(63.7 \%)$ and was strongly correlated with water temperature $(r=0.51)$, largely separating site 1 (Santa Barbara) from the other sites (Fig. 2). The first axis accounted for $17.8 \%$ of the variance and was associated with elevation and current velocity ( $r=0.88$ and 0.42 , respectively). The analysis of the trophic matrix produced similar results (Table 2). Two axes accounted for $88.6 \%$ of the variation. The second axis $(31.1 \%$ of the variation) separated site 1 from the other sites (Fig. 3), and it was strongly correlated with elevation and current velocity $(r=0.70$ and 0.51 , respectively). The first axis, representing $57.5 \%$ of the variation also was strongly associated with elevation $(r=$ $0.84)$ and velocity of flow $(r=0.52)$.

For the basin-level comparison using trophic matrices, two axes accounted for $77.5 \%$ of the variation. The first axis represented $21.8 \%$ of the variation, whereas the third axis accounted for $49.7 \%$. The multiresponse permutation analysis indicated a significant difference in trophic groups between the two basins $(\mathrm{A}=0.224, P=0.0001$; Fig. 4).

Discussion-Many systems in central Mexico have been severely impacted by anthropogenic activities such as extraction of water, construction of dams, and introduction of exotic species. Such changes potentially contribute to the organization of assemblages of fishes. In addition, biotic and natural abiotic factors, such as chemistry of water, structure of habitat, predation, and competition, also affect local abundances and distributions of species. Furthermore, spatial and temporal 

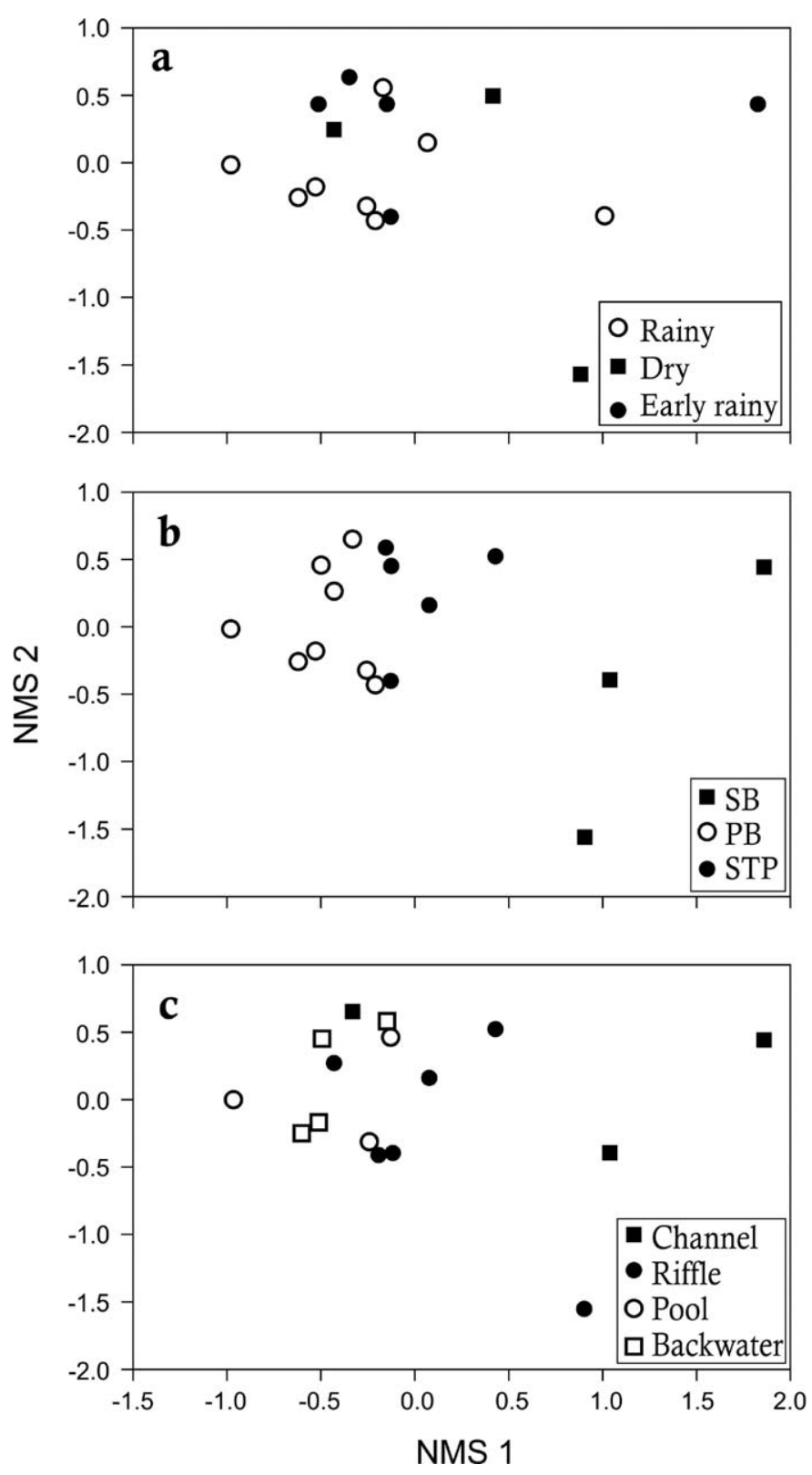

FIG. 2-Results of nonmetric multidimensional scaling (NMS) analysis of a) seasons, b) sites, and c) habitat based on the taxonomic matrix of abundances of species in the Tilostoc River in central Mexico. For sites, SB = Santa Barbara, PB = Planta de Bombeo, and STP = Santo Tomas de los Platanos. The first and second axes accounted for 63.7 and $17.8 \%$ (respectively) of variation in the original data matrix.

patterns of assemblages of fishes may depend on the type of biological data used (taxonomic or functional groupings). Trophic groups are often thought to reflect ecological relationships better than taxonomic groups, especially when assessing the functional effects of environmental impacts (Higgins, 2010). However, if the trophic matrix is built from the taxonomic matrix, some level of dependency will always be present. Recently, it has been suggested that, despite correlations between functional and taxonomic groupings, the functional structure
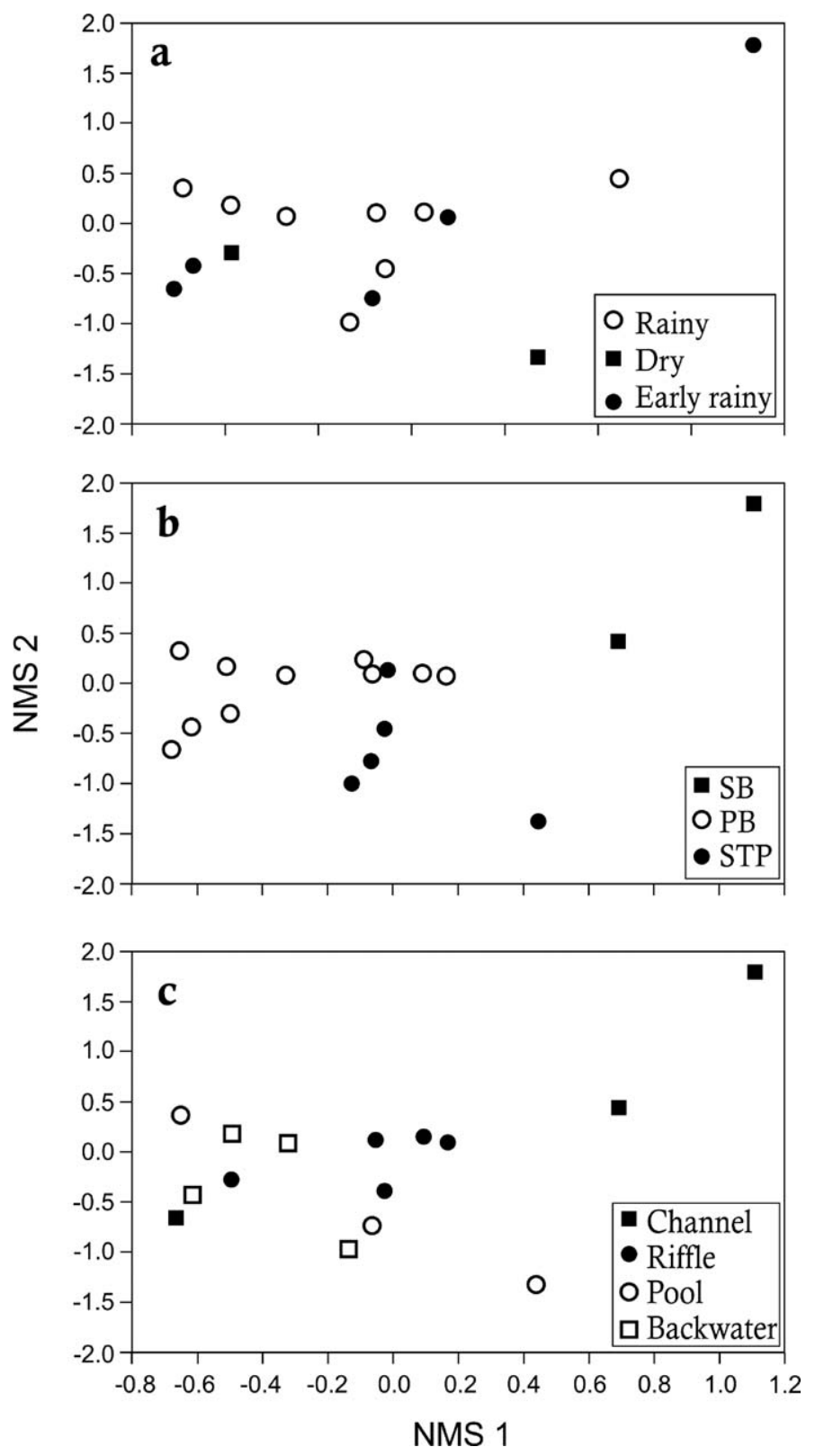

FIG. 3-Results of nonmetric multidimensional scaling (NMS) analysis of a) seasons, b) sites, and c) habitat based on a matrix of trophic groupings of fish in the Tilostoc River in central Mexico. For sites, $\mathrm{SB}=$ Santa Barbara, $\mathrm{PB}=$ Planta de Bombeo, and STP = Santo Tomas de los Platanos. The first and second axes accounted for 57.5 and $31.1 \%$ (respectively) of variation in the original data matrix.

of assemblages largely depends on intracommunal (alpha diversity) components, whereas the taxonomic structure is more dependent on intercommunal (beta diversity) components; therefore, both groupings have ecological value (Hoeinghaus et al., 2007; Higgins, 2010).

Our nonmetric multidimensional scaling analyses suggested that trophic and taxonomic groups responded similarly to environmental conditions, with velocity of current, temperature, and elevation showing strong associations in both analyses. Elevation was the strongest 


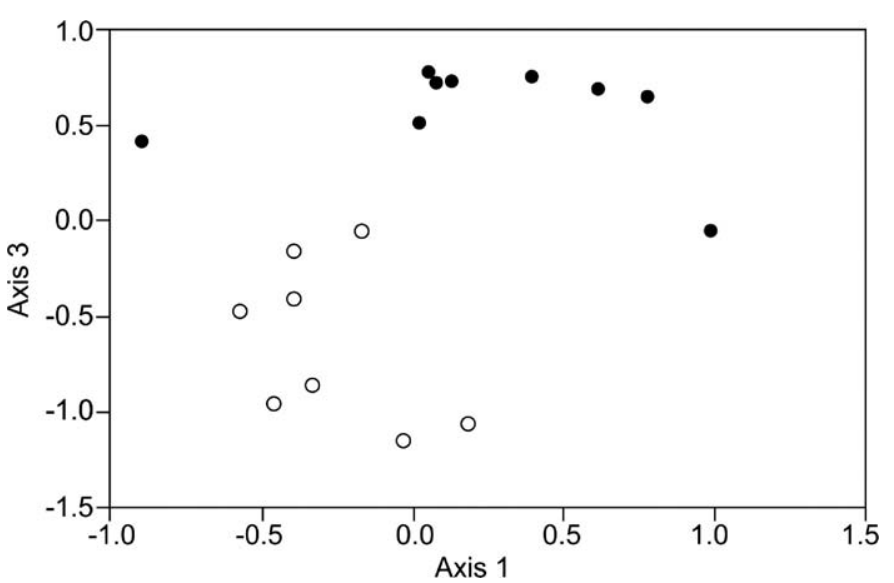

FIG. 4-Results of nonmetric multidimensional scaling (NMS) analysis based on trophic groups of fish from the Tilostoc River (solid circles) and Terreros Creek (open circles) in the Balsas and Lerma basins (respectively) in central Mexico. First and third axes accounted for 21.8 and $49.7 \%$ (respectively) of variation in the original data matrix.

correlate of structure of assemblages in trophic and taxonomic analyses, regardless of season or type of microhabitat. The highest site (Santa Barbara), which was in close proximity to the dam, had the most differentiated assemblage of fishes. This site contained only two species, both introduced. Numerous studies have described the impact of construction of dams on the establishment of exotic species, and their appearance has coincided with construction of reservoirs in Mexico (Ruiz, 1998; Prenda et al., 2002). Thus, we reiterate the importance of documenting the influence of human disturbances on the structure and composition of assemblages of fishes throughout Mexico to prevent further loss of biodiversity.

When comparing the two river basins in central Mexico, significant differences were found based on structure of trophic guilds, indicating the importance of historic constraints on trophic structure as well as taxonomy. Only one species, Notropis sallei, was shared among basins. Notropis sallei is an endemic species with a restricted geographic distribution in central Mexico. The major threats to $N$. sallei are those associated with constructions of dams (Diaz-Pardo et al., 1993), a shared characteristic of both basins in our study. We found two endemic species in the Tilostoc River (Balsas Basin), Ictalurus balsanus, the only piscivorous species present, and Ilyodon whitei, the only herbivore. In the Lerma Basin, Terreros Creek contained two species of the genus Chirostoma (C. humboldtianum and C. jordani), which were the only zooplanktivorous species found in this study. When comparing species richness between both systems, we observed 12 species in the Tilostoc River and only five species in Los Terreros Creek; however, both basins were similar in the proportion of native to introduced species. Regarding introductions of species, two species (Microp- terus salmoides and Lepomis cyanellus) were introduced as sport fishes in the Tilostoc River, whereas Oreochromis urolepis hornorum was introduced as a food fish. Similarly, Cyprinus carpio and Chirostoma humboltianum were introduced as food fishes in Terreros Creek. Thus, although the basins share a similar combination of physical and environmental characteristics, anthropogenic effects and historical constraints strongly influenced the ecological patterns we found and provided a unique combination of attributes that determined structure of assemblages within these basins.

Our study presents the first description and classification of assemblages of fishes inhabiting the Tilostoc River in the middle Balsas Basin. The challenge of conserving tropical biodiversity in a world of rapidly growing human populations requires accurate inventories of species and their habitats but also the understanding of the mechanisms that create and maintain patterns of biodiversity. The Tilostoc River in the State of Mexico is one of the few rivers in the Balsas Basin that have not been adequately surveyed regarding biodiversity of fish, despite the fact that it provides Mexico City with municipal water supply.

We thank T. Contreras-MacBeath, and I. Preciado-Chino for help in the field and landowners along the Tilostoc River for allowing access. F. Mendez provided data for Los Terreros Creek. Funding was provided by The National Council on Science and Technology (CONACYT). M. Beierle produced the map shown in Fig. 1 using $\operatorname{ArcGIS}^{\circledR}$ (Esri, Redlands, California).

\section{Literature Cited}

BILlard, R. 1997. Les poissons d'eau douce des rivières de France. Identification, inventaire et répartition des 83 espèces. Delachaux et Niestlé, Lausanne, Switzerland.

Bussing, W. A. 1998. Peces de las aguas continentales de Costa Rica. Second edition. Universidad de Costa Rica, San José.

Comisión Nacional para el Conocimiento y Uso de la BiodiversiDAD. 1998. La diversidad Biológica de México: estudio de país, 1998. Comisión Nacional para el Conocimiento y Uso de la Biodiversidad, Distrito Federal, México.

Contreras-Balderas S., G. Ruiz-Campos, J. J. Schmitter-Soto, E. Díaz-Pardo, T. Contreras-Macbeath, M. Medina-Soto, L. Zambrano-González, A. Varela-Romero, R. Mendoza-Alfaro, C. Ramírez-Martínez, M. A. Leija-Tristán, P. Almada-Villela, D. A. Hendrickson, and J. Lyons. 2008. Freshwater fishes and water status in Mexico: a country-wide appraisal. Aquatic Ecosystem Health and Management 11:246-256.

Contreras-Macbeath, T. 2005. Fish conservation in Mexico with emphasis in livebearing species. Pages 401-414 in Viviparous fishes (M. C. Uribe and H. J. Grier, editors). New Life Publications, Homestead, Florida.

Contreras-Macbeath, T., and E. Soto Galera. 1991. Peces dulceacuícolas Mexicanos VI. Ictalurus balsanus (PISCES: ICTALURIDAE). Zoología Informa 23:10.

Díaz Pardo, E., M.A. Godínez Rodríguez, E. López-López, and E. Soto-Galera. 1993. Ecología de los peces de la cuenca del río Lerma, México. Anales de la Escuela Nacional de Ciencias Biológicas, Instituto Politécnico Nacional, México 39:103127. 
Gauch, H. G. 1982. Multivariate analysis in community ecology. Cambridge University Press, New York.

Harrison, I. J., and M. L. J. Stiassny. 1999. The quiet crisis: a preliminary listing of the freshwater fishes of the world that are extinct or "missing in action." Pages 271-331 in Extinctions in near time: causes, contexts, and consequences (R. D. E. McPhee, editor). Kluwer Academic/Plenum Publishers, New York.

Hawkins, C. P., J. L. Kershner, P. A. Bisson, M. D. Bryant, L. M. Decker, S. V. Gregory, D. A. Mccullough, C. K. Overton, G. H. Reeves, R. J. Steedman, And M. K. A. Young. 1993. Hierarchical approach to classifying stream habitat features. Fisheries 18(6):3-12.

Higgins, C. L. 2010. Patterns of functional and taxonomic organization of stream fishes: inferences based on $a, b$, and $g$ diversities. Ecography 33:678-687.

Hoeinghaus, D., K. Winemiller, and J. Birnbaum. 2007. Local and regional determinants of stream fish assemblage structure: inferences based on taxonomic vs. functional groups. Journal of Biogeography 34:324-338.

Instituto Nacional de Estadística Geografía e Informática. 2000. Indicadores de desarrollo sustentable en México. Instituto Nacional de Estadística Geografía e Informática e Instituto Nacional de Ecología, Distrito Federal, Mexico.

Jackson, D. A., AND K. M. Somers. 1991. Putting things in order: the ups and downs of detrended correspondence analysis. American Naturalist 137:704-712.

Legendre, P., And L. Legendre. 1998. Numerical ecology. Second English edition. Elsevier Science BV, Amsterdam, The Netherlands.

Matthews, W. J. 1998. Patterns in freshwater fish ecology. Chapman and Hall, New York.

Mccune, B., AND J. B. Grace. 2002. Analysis of ecological communities. MjM Software Design, Gleneden Beach, Oregon.

Mccune, B., And M. J. Mefford. 2006. Multivariate analysis of ecological data. Version 5. MjM Software, Gleneden Beach, Oregon.

Miller, R. R. 2005. Freshwater fishes of México. University of Chicago Press, Chicago, Illinois.

Mills, D., And G. Vevers. 1989. The Tetra encyclopedia of freshwater tropical aquarium fishes. Tetra Print, Englewood, New Jersey.

Mittermeier, R., And C. Goettsch Mittermeier. 1997. Megadiversidad. Los países biológicamente más ricos del mundo. Cementos Mexicanos, México.

Moyle, P. B., AND J. J. CeCh, JR. 2000. Fishes: an introduction to ichthyology. Second edition. Prentice-Hall, Englewood Cliffs, New Jersey.

Organización para la Cooperación y el Desarrollo Económico. 1998. Análisis del desempeño ambiental, México. Organ- ización para la Cooperación y el Desarrollo Económico, Distrito Federal, México.

Prenda, J., M. Clavero, F. Blanco, and A. Rebollo. 2002. Consecuencias ecológicas de la creación de embalses en el ámbito mediterráneo: el caso de los peces. Pages 497-503 in Actas del III Congreso Ibérico de Gestión y Planificación del Agua (L. Moral, coordinator). Sevilla, México.

RuIz, A. 1998. Fish species composition before and after construction of a reservoir on the Guadalete River (Spain). Archiv für Hydrobiologie 142:353-369.

Ruiz-Gomez, L., J. Mendez-Sanchez, F. Rodriguez-Romero, and C. TAYLOR. 2008. Spatiotemporal changes in fish assemblages of Los Terreros creek, an isolated stream system in headwaters of the Lerma River, central Mexico. Southwestern Naturalist 53:224-229.

Taylor, C. M., T. L. Holder, R. A. Fiorillo, L. R. Williams, R. B. Thomas, AND M. L. Warren. 2005. Distribution, abundance, and diversity of stream fishes under variable environmental conditions. Canadian Journal of Fisheries and Aquatic Sciences 63:43-54.

Trewavas, E. 1983. Tilapiine fishes of the genera Sarotherodon, Oreochromis and Danakilia. British Museum of Natural History, London, United Kingdom.

Trujillo, P. 1998. Dinámica trófica de la ictiofauna del río Amacuzac, Morelos. Tesis de M. en C., Facultad de Ciencia Biológicas, Universidad Autónoma del Estado de México, Morelos, México.

Trujillo Jimenez, P. 1998. Trophic spectrum of the cichlids Cichlasoma (Parapetenia) istlanum and Cichlasoma (Arconcentrus) nigrofasciatum in the Amacuzac River, Morelos, Mexico. Journal of Freshwater Ecology 13:465-473.

Trujillo Jimenez, P., And E. Diaz-Pardo. 1996. Espectro trófico de Ilyodon whitei (Pisces:Goodeidae) en el río del Muerto, Morelos. Revista de Biología Tropical 44:755-761.

Trujillo Jimenez, P., And H. Toledo Beto. 2007 Alimentación de los peces dulceacuícolas tropicales Heterandria bimaculata y Poecilia sphenops (Cyprinodontiformes: Poeciliidae). Revista de Biología Tropical 55:603-615.

Wartenberg, D., S. Ferson, and F. J. Rohlf. 1987. Putting things in order: a critique of detrended correspondence analysis. American Naturalist 129:434-448.

Wootton, R. J. 1990. Ecology of teleost fishes. Chapman and Hall, New York.

Wootton, R. J. 1992. Constrainst in the evolution of fish life histories. Netherlands Journal of Zoology, 42:291-303.

ZARET, T. M., AND A. J. RAND. 1971. Competition in tropical stream fish communities. Ecology 59:507-515.

Submitted 25 October 2011. Acceptance recommended by Associate Editor Robert J. Edwards 21 December 2012. 
Reproduced with permission of the copyright owner. Further reproduction prohibited without permission. 